Digital Press Social Sciences and Humanities

Readiness for Change Reviewed from Intrapreneurship and Perception of Career Development

I Gde Dhika Widarnandana and Sumaryono

Proceeding of The 10th International Conference of Indigenous and Cultural

Psychology 2019

Kwartarini Wahyu Yuniarti, Donald H. Saklofske, Rosnah Ismail, Saadi Lahlou (eds) 


\title{
Readiness for Change Reviewed from Intrapreneurship and Perception of Career Development
}

\author{
I Gde Dhika Widarnandana ${ }^{1, *} \&$ Sumaryono ${ }^{2}$ \\ 1 Psychology Study Program, Dhyana Pura University, Badung, Bali, Indonesia \\ 2 Psychology Faculty, Gadjah Mada University, Yogyakarta, Indonesia \\ *e-mail: gdedhika@undhirabali.ac.id
}

\begin{abstract}
Change is necessary for a company to survive in the global competition. Intrapreneurship and perception of career development are essentials in allowing companies to be responsive. The purpose of this study is to investigate whether intrapreneurship and career development perception are predictors of readiness for change. This study involved 193 employees who have worked at least two years and have a minimum high school degree. Several measurement tools were used: (1) employee readiness for change scale with the reliability $0.827,(2)$ intrapreneurship scale with a reliability score of 0.912 , and (3) perception of career development scale with a reliability score of 0.873 . Respondents were recruited using a purposive sampling technique. Data were analyzed using multiple regression analysis. The results of this study achieve a value of $\mathrm{p}<0.05$ and $\mathrm{R} 2=0.414$, indicating that intrapreneurship and perception of career development contribute $41.4 \%$ in explaining employees' readiness for changes. Thus, this research becomes an important study of employee readiness for change.
\end{abstract}

\section{Keywords}

career, intrapreneurship, readiness for change

\section{Introduction}

Indonesia is a developing country in which since 2015 it has been applying a program called mental revolution. This program is applied by utilizing six values that are separated into three sectors, videlicet: the politic sector that comprises of credible and human values, the cultural sector that consists of respect and cooperative values, and the economic sector that includes independent and creativity values (Kurniawan, 2015). The economy sector that includes independent value has immense meaning as each nation must have this value in every aspect and encourage its citizens to be more productive and creative in order to make it advanced and wealthy.

Improving the economy sector, a nation needs support from a company. There are two kinds of companies in Indonesia such as private companies and state-owned companies (BUMN). The number of the enlisted state-owned company in Indonesia right now is approximately 119 (BUMN, 2017). These companies give income to the government via tax, besides they also have a role in creating opportunities to work for labor in Indonesia. These companies surely have a goal to be able to face the global situation that is getting more competitive.

The development inside of the company can be done by manufacturing some innovations not only in the work system but also in the culture of the company so that it can cause a change that can occur anytime in the organization of the company. A change is needed in a company to make it survived, nevertheless to implement it successfully is not an easy job to do (Kreitner \& Kinicki, 2005). An organization nowadays faces a big challenge in organizing a change effectively. When an organization fails to implement a change, it will increase the cost. In order to handle the dynamic environment, an organization needs to have the capacity to adapt quickly to salvage itself (Hanpachern, Morgan, \& Griego, 1998). Batch, Castaneda and Farah (2013) also states that this time an organization has to be able to change to match itself with the market change, hence it needs an employee having a capability (readiness) to handle a change that happens in the company.

A readiness to change basically is a step from the concept given by Lewin that is at the unfreezing stage, in which it is the beginning step in implementing a change (Choi \& Ruona, 2011). A change will 
always be existent in each company in which sometimes it creates uncertainty occurrence. It does not only happen in the private sector but also in the state-owned company too, even though it is regulated by the government. Nowadays, the rule of the law discourages the state-owned company to do the monopoly anymore so that it departs comfort zone and becomes active in a competition (Kasali, 2014). Then, it encourages an employee to have an eagerness to face a change.

Based on the preliminary study that has been conducted by the researcher at $26^{\text {th }}$ of May $-3^{\text {rd }}$ of June 2017 via survey toward 21 subjects having worked both in the government institution and private sector with a criterion such as the work period about 1-3 years stating that the aforementioned subjects happened a change related to a system or their duties on their job. A change that happened mostly at their job description requires the subjects to handle the new task. As a consequence of it, the subjects have to adapt themselves quickly toward the condition.

Readiness toward a change consists of four compiling aspects for instance self-efficacy, it is a personal belief that he or she is able to make a change coming from each individual and group that have the capability to achieve a change. Next, appropriateness, it is a change that is done accordingly to be implemented so that all individuals are willing to contribute to making a change. Afterward, management support, it is an action done by a leader to support and commit to making a change. The last is the personal benefit that means a change that gives benefit or profit both intrinsic and extrinsic for the sake of individual change (Holt, Armenakis, Feild, \& Harris, 2007).

Considering the importance of the readiness toward a change in an organization, thus it needs an effort from the employees to have a readiness toward a change that can happen both to the system and the work environment. A change inside a company can be done by creating some new products and services, also the new business strategy. In a study conducted by Karimi, Malekmohamadi, Daryani \& Rezvanfar (2011), it stated that it needed intrapreneurship attitude in handling a change that might come.

Intrapreneurship is a term that is used for a mid-high company having entrepreneurial characteristics (Dhewanto, 2013). Intrapreneurship influences the performance inside the organization specifically the development and improvement factors. These factors are needed when the organization prepares to make a change so the employees are ready in embracing sustainable development and improvement in a company (Friana \& Indriana, 2015).

An intrapreneur is different from an ordinary employee (Kasali, 2010). Intrapreneur works step by step quickly as he or she has an orientation on some breakthroughs and opportunities. The benefit of having intrapreneurship employees is that he or she will work more actively and more enthusiastic inside his or her company. The overseas companies such as Apple Inc, Walt Disney, Unilever, and the domestic companies such as Indofood, PT Telkom, Sinar Mas are examples of the companies that implement intrapreneurship inside their companies (Dhewanto, 2013). Intrapreneurship can be done by providing an opportunity for the employees to take part in developing the company. Intrapreneurship is not only needed by the employees that have a role in a higher position but also needed for the new and young employees inside the company.

In this case, intrapreneurship is an employee having entrepreneurship characteristics on their personality in which it has three compiling aspects namely innovation, risk-taking, and proactive (Kurnia \& Simarmata, 2014). Innovation talks about a person that can produce a new idea. It brings a benefit in doing his or her job, for instance, make a job more efficient (Amir, 2016). Next, risk-taking, it is the condition in which the employees are able to consider something that he or she faces and courageously take a risk in making a change. The next is proactive, it talks about the employees who take part actively in developing and improving the company.

Apart from having intrapreneurship characteristics in the organization, the employees also need to have a career development perception well toward the company where he or she works. Having this perception, the employees are able to be more aware, alert, and prepared toward a change inside the company. Pradana (2010) explained that an employee who has a negative perception tends to think that career development cannot increase his or her performance, work less effort, and discourage his or her career development. It makes the change in the company works slowly. Career development is a process during which an employee does the progress through a couple of steps in which each step characterized by the number of differences such as the more developed duty (Melinda \& Zulkarnain, 2004). The perception of career development can be said as an employees' opinion toward his or her career development in a company.

Improving carriers in a company refer to four aspects, namely: the increase of the responsibility, the status of the title or position, authority, and compensation given to the employees (Flippo \& Sirait, 1992). The responsibility means that an obligation to do the duty and task given to them as a consequence of the authority. The status of title or position is defined as a role showing the position of employees in a chain 
or a structure inside the organization. While, the authority means a formal power owned by a person to act, give an order, and do the activities in the organization. Meanwhile, the compensation is an income in the form of money, direct or indirect goods accepted by the employees as a reward for what he or she does to the company.

One of the companies that nowadays is implementing a change in Company X. Company X is a company that works in the manufacturing sector, precisely at the integrated steel industry, and has been established since 1970. Based on the result during the psychology profession program internship that is done by the researcher from August to December 2016, it was obtained that at that time the company was changing its orientation into market-oriented. The company moved actively in promoting its product to relish the challenge of the steel sale. It could be seen from the structural system that the company also has combined some divisions to make it efficient. Meanwhile, the human resource view described that the company at that time had a high enough age disparity as the company had the policy to apply zero recruitment policy for ten years causing the company's employees specifically the new employees to make a quick adaptation and adjust his or her self with the established system.

Right now, Company X in 2017 has the new managing director who has a vision that the company must be able to cope with a change in which here means that the employees are eager to support a change for instance, from being lazy to diligent, unaware into aware, mediocre changes into excellent, and misunderstanding their duties to understanding their duties, and also reckless into discipline. The managing director also explains that the root problem in Company $\mathrm{X}$ is the employees of the company who have not been able to move on from the zone in the past to the present one, then the employees also still think inside the box, and also the board is not brave enough to make a decision (KSG, 2017). The interview was conducted with the two employees of the Company X on 12 of September 2017. The result of the interview stated that the company experienced a change related to the working mentor so that it needs an adaptation on how to work collaboratively with each mentor. Besides, the company also experienced a change in the procedure related to the work system in the company.

Based on the given data above, the researcher considers the importance of the readiness on a change viewed from intrapreneurship and the career development perception for the company. Hence, the researcher does the research under the hypothesis called "intrapreneurship and the carrier development perception are the predictors of a readiness to change".

\section{Methods}

This research utilizes the quantitative methodology by distributed survey using three kinds of psychology scale as the method of data collection. There are two variables here, the dependent variable and the independent one. The independent variable is the variable that influences or causes a change or creates the dependent variable (Sugiyono, 2015). The independent variable here consisted of two things, which are intrapreneurship and the career development perception. Intrapreneurship is an employee's characteristics on how he or she is able to think, feel, and act like an entrepreneur in the organization to face a challenge for instance innovation, proactive, and risk-taking that is measured using intrapreneurship scale. The career development perception is an interpreting and organizing process a series of activities and behaviors of a person related to his or her work comprising of responsibility, the status of role or position, authority, and compensation measured by using the career development perception scale. The dependent variable is the variable that is influenced or that rises because of the independent variable. The dependent variable here refers to readiness for change. Readiness for change is described as a sensitive attitude toward a change that always against the quo status and also has a belief to succeed in a change that comprises self-efficacy, appropriateness, management support, and personal benefit that are estimated using the scale of the readiness for change.

The subject of this research was the employees of Company X. The data was taken using a purposive sampling technique, a technique which deploys special criteria toward the subject of the research, then the researcher found the subject fulfilling the criteria that have been set (Periantalo, 2016). Concerning the criteria of the subject that has been set for instance:

The male and female employees have been working at least two years in the company. It shows that the employees have fully understood his or her work environment. Having graduated senior high school at least as the education degree, it reflects that the subjects are able to comprehend deeply to the scale given by the researcher. The scale measurement here utilizes 5 choices namely: strongly disagree (STS), Disagree (TS), Neutral (N), Agree (S), Strongly Agree (SS). The favorable statement has a rule in providing 
the score as follows: the strongly disagree answer (STS) equals to 1, the disagree answer (TS) equals to 2 , the neutral answer $(\mathrm{N})$ reflects 3 , the agree answer $(\mathrm{S})$ represents 4 , and the strongly agree (SS) is given 5. While, the unfavorable statement has another rule in giving the score such as; the strongly disagree answer (STS) is given 5, the disagree answer (TS) gets 4, the neutral answer (N) obtains 3, the agree answer (S) will be given 4, and the strongly agree answer (SS) will obtain 5 . The scale used in this research will be described below:

\subsection{The Scale of Readiness for Change}

This scale is adapted from the research conducted by Zulkarnain \& Hadiyani (2014) that refers to the theory proposed by Holt, Armenakis, Field \& Harris (2007) comprising of four aspects namely: selfefficacy, appropriateness, management support, and personal benefit. The higher score obtained in this questionnaire, the readier of the employee to face a change. On the other hand, the lower score obtained through this questionnaire, the less ready of a subject to cope with a change. The scale here has 0,928 as reliability.

Table 1 The blueprint of the readiness for change scale

\begin{tabular}{lllc}
\hline No & \multicolumn{1}{c}{ Aspect } & Item & Amount \\
\hline 1 & Self Efficacy & $1,2,4,17,19$ & 5 \\
2 & Appropriateness & $8,14,16,18,20,21$ & 6 \\
3 & Management Support & $3,5,6,7,13$ & 5 \\
4 & Personal Benefit & $9,10,11,12,15$ & 5 \\
\hline & & \\
& &
\end{tabular}

\subsection{The Intrapreneurship Scale}

This scale is composed of modifying to the scale used by Deinta (2013) that is following the research conducted by Jong, Parker, Wennekers \& Wu (2011). This scale consists of three aspects namely innovation, proactive, and risk-taking. The higher score obtained means the higher the subject having intrapreneurship characteristics. In contrast, the lower score obtained by the subject, the lower of the subject having intrapreneurship characteristics. 
Table 2 The blueprint of the intrapreneurship scale

\begin{tabular}{|c|c|c|c|c|}
\hline \multirow{2}{*}{ No } & \multirow{2}{*}{ Aspect } & \multicolumn{2}{|l|}{ Item } & \multirow{2}{*}{ Amount } \\
\hline & & Favorable & Unfavorable & \\
\hline 1 & Inovation & $1,7,9,20$ & $3,11,14,18$ & 8 \\
\hline 2 & Proaktive & $2,12,22,24$ & $8,13,15,17$ & 8 \\
\hline 3 & Risk-taking & $6,16,19,23$ & $4,5,10,21$ & 8 \\
\hline & Total & & & 24 \\
\hline
\end{tabular}

\subsection{The Career Development Perception Scale}

This scale is composed by the researcher based on the theory stated by Flippo \& Sirait (1992). This scale consists of four aspects namely responsibility, the status of title/position, authority, and compensation. The higher score obtained on this questionnaire, the higher the perception of career development. On the one hand, the lower score obtained, the lower the perception in improving the carrier owned by the subject.

Table 3 The blueprint of the career development scale

\begin{tabular}{|c|c|c|c|c|}
\hline \multirow{2}{*}{ No } & \multirow{2}{*}{ Aspect } & \multicolumn{2}{|l|}{ Item } & \multirow{2}{*}{ Amount } \\
\hline & & Favorable & Unfavorable & \\
\hline 1 & Responsibility & $1,7,18,23$ & $8,13,17,31$ & 8 \\
\hline 2 & Status of title/position & $9,16,19,28$ & $5,11,21,26$ & 8 \\
\hline 3 & Authority & $2,10,22,30$ & $3,6,24,25$ & 8 \\
\hline 4 & Compensation & $4,15,27,32$ & $12,14,20,29$ & 8 \\
\hline & Total & & & 32 \\
\hline
\end{tabular}

The design or plan that is deployed for guiding the plan on how the research is going to be implemented. This research deploys quantitative design without any intervention in which it connects variables in one predictable scheme for some individuals. The researcher uses survey planning by giving the scale to one sample of the research in describing the attitude, opinion, behavior, or characteristics of the subject (Alsa, 2007).

The procedure of this research consisted of three stages, namely: the preparation stage, the datacollection stage, and the data-analysis stage. First, the preparation stage was done by proposing a proposal and a permission letter to conduct the research in the name of Magister of Psychology 
Profession Program, Faculty of Psychology, Universitas Gadjah Mada on Company X. Second, the data collection stage was done by spreading the scales to the employees matching the criteria. Third, the data analysis stage refers to the scoring toward the data by the researchers, then he or she analyzed using an application on statistic analysis. The method of the analysis is conducted by utilizing the doubled regression analysis in which the analysis was done toward one dependent variable and two independent variables (Yudiaatmaja, 2013). The independent variable in this research here refers to intrapreneurship and the career development perception, while the dependent variable refers to readiness for change.

\section{Result}

Before conducting the research, the researcher prepared by testing the validity and the reliability from the scale of the research. The first test was conducted by checking the validity via Aiken test $\mathrm{V}$ in which the assessment was done by the 32 subjects matter expert coming from the postgraduate students of the Master of Psychology Profession Program. The assessment was done from 9 to 15 August 2017. The result of the validity test toward the intrapreneurship moved from $0,641-0,859$. While the result of the validity test on the career development perception moved from $0,68-0,867$. The following test used to find out the reliability difference of the measuring instrument by trying it out that was done from 18 to 23 August 2017. The tryout action was conducted to 40 respondents having characteristics of the subject of the research. The results of the analysis are shown below:

\subsection{The Scale of Readiness for Change}

The scale of readiness for change has reliability around 0,827 , in which there are 5 aborted items on number 4, 8, 9, 11, 16 after having filtered through validity test. The validity score moved from the range number $0.344-0.597$.

Table 4 The numbering of readiness for change scale after trying out

\begin{tabular}{llll}
\hline No & Aspect & Item & Amount \\
\hline 1 & Self Efficacy & $1,2,12,14$ & 4 \\
& & & \\
2 & Appropriateness & $10,13,15,16$ & 4 \\
3 & Management Support & $3,4,5,6,9$ & 5 \\
4 & Personal Benefit & $7,8,11$ & 3 \\
\hline & & & \\
& &
\end{tabular}

\subsection{Intrapreneurship Scale}

Intrapreneurship scale has reliability about 0.912 , in which there is one aborted item on number 23 . The validity score moved from number around $0.338-0.597$. 
Table 5 The numbering of the intrapreneurship scale after trying out

\begin{tabular}{|c|c|c|c|c|}
\hline \multirow{2}{*}{ No } & \multirow{2}{*}{ Aspect } & \multicolumn{2}{|l|}{ Item } & \multirow{2}{*}{ Amount } \\
\hline & & Favorable & Unfavorable & \\
\hline 1 & Innovation & $1,7,9,20$ & $3,11,12,14$ & 8 \\
\hline 2 & Proaktive & $2,18,22,23$ & $8,13,15,17$ & 8 \\
\hline \multirow[t]{2}{*}{3} & Risk-taking & $6,16,19$ & $4,5,10,21$ & 7 \\
\hline & Total & & & 23 \\
\hline
\end{tabular}

\subsection{The Career Development Perception Scale}

The career development perception scale Has reliability around 0.873 , where there are twelve aborted items on the following numbers $1,2,3,4,6,7,10,11,14,19,26,27$. The validity value moved from the number around $0.328-0.599$.

Table 6 The numbering of the career development perception scale after trying out

\begin{tabular}{|c|c|c|c|c|}
\hline \multirow{2}{*}{ No } & \multirow{2}{*}{ Aspect } & \multicolumn{2}{|l|}{ Item } & \multirow{2}{*}{ Amount } \\
\hline & & Favorable & Unfavorable & \\
\hline 1 & Responsibility & 9,13 & $2,5,8,19$ & 6 \\
\hline 2 & Status of title/position & $3,7,16$ & 1,11 & 5 \\
\hline 3 & Authority & 12,18 & 14,15 & 4 \\
\hline 4 & Compensation & 6,20 & $4,10,17$ & 5 \\
\hline & Total & & & 20 \\
\hline
\end{tabular}

Then, the researcher did the data collection of the research starting from 24 August to 8 September 2017, with the total of the gathered subjects around 193 taken from 6 Directorates in Company X. The researcher also did the note-taking to the demography information of the employee viewed from age, gender, status, duration of work, and the degree of the education.

The researcher wrote the description of the research data from the mean, the standard of deviation, the lowest score, and the highest score as described below: 
Table 7 The description of the research data

\begin{tabular}{lccccc}
\hline Description of the Data & N & Mean & SD & XMin & XMax \\
\hline A readiness for change & 193 & 58,60 & 7,095 & 40 & 78 \\
& 193 & 89,23 & 6,765 & 73 & 110 \\
$\begin{array}{l}\text { Intrapreneurship } \\
\begin{array}{l}\text { The career development } \\
\text { perception }\end{array}\end{array}$ & 193 & 68,78 & 9,614 & 43 & 100 \\
\hline
\end{tabular}

Based on Table 7, 193 subjects of the research have an empirical mean value of around 58.60 on its readiness for change scale, its deviation standard is about 7.095 with 40 as the minimum value, and the maximal value is 78. Then, the intrapreneurship scale has 89.23 as the empirical mean, its deviation standard is 6.765 with its minimum value is 73 and the maximal value is 110 . Meanwhile, the career development perception scale has 68.78 as the empirical mean value, its deviation standard is 9.614 with its minimum value around 43 and the maximal one is 100 .

In order to know the degree of the research scale, the researcher also did a comparison between the hypothetical mean and the empirical mean that can be seen in the following table.

Table 8 The hypothetical and empirical mean

\begin{tabular}{lll}
\hline Scale & Hypothetical Mean & Empirical Mean \\
\hline Readiness for change & 48 & 58.60 \\
& 69 & 89.23 \\
Intrapreneurship & & 68.78 \\
\hline
\end{tabular}

From Table 8, it is known that the value of hypothetical mean from the scale of readiness for change is 48 , which is lower than the value of empirical mean which is 58.60 . The intrapreneurship scale has a hypothetical mean of around 69, which is lower than the 89.23. as the empirical mean. The career development perception scale is 60 that is lower than the empirical mean which is 68.78 . It reflects that every scale shows the highest average value.

The researcher did the characteristics test toward the demography data obtained with readiness for change. This test is conducted by the researcher by using the parametrical statistic test due to the demography data belonged to the normal data. 
Table 9 The demography based analysis

\begin{tabular}{ll}
\hline Demography & Sig \\
\hline Gender & 0.389 \\
Age & 0.714 \\
& 0.145 \\
Duration of work & \\
Education & 0.871 \\
The degree of the job & 0.102
\end{tabular}

In the analysis of the difference test on the two samples given, the researcher utilizes the independent sample t-test parametrical analysis, while the difference test on more than two samples, the researcher used a one-way ANOVA test (Santoso, 2014). Table 9 shows that the score of the demography data is $>0.05$, thus there is no difference among readiness for change of the employees if it is based on the demography data such as gender, age, the duration of work, education, and the degree of the job.

The researcher also categorized the individuals by placing them into a separate group based on the measured attributes. The researcher does the categorization into five groups namely very low, low, normal, high, and very high. The formula of the categorization of the research score on the variables of readiness for change, intrapreneurship, and the career development perception will be explained in the following table.

Table 10 The categorization score of readiness for change

\begin{tabular}{|c|c|c|c|}
\hline Range & Category & Amount & Percentage \\
\hline$X \leq 31.95$ & Very low & 0 & $0 \%$ \\
\hline $31.95<X \leq 42.65$ & Low & 3 & $1.56 \%$ \\
\hline $42.65<X \leq 53.35$ & Normal & 41 & $21.24 \%$ \\
\hline $53.35<X \leq 64.05$ & High & 117 & $60.62 \%$ \\
\hline \multirow[t]{2}{*}{$64.05<X$} & Very high & 32 & $16.58 \%$ \\
\hline & Total & 193 & $100 \%$ \\
\hline
\end{tabular}

Based on the result of the analysis on the readiness for change scale, it is known that the subject is dominated on the high categorization which is $60.62 \%$ or 117 people, while the normal categorization is around $21.24 \%$ or 41 people, and the last, the high categorization is $16.58 \%$ or 32 people and the low categorization is $1.56 \%$ or 3 people. 
Table 11 The categorization of the intrapreneurship score

\begin{tabular}{|c|c|c|c|}
\hline Range & Category & Amount & Percentage \\
\hline$X \leq 46.05$ & Very low & 0 & $0 \%$ \\
\hline $46.05<X \leq 61.35$ & Low & 0 & $0 \%$ \\
\hline $61.35<X \leq 76.65$ & Normal & 9 & $4.6 \%$ \\
\hline $76.65<X \leq 91.95$ & High & 114 & $59.1 \%$ \\
\hline \multirow[t]{2}{*}{$91.95<X$} & Very high & 70 & $36.3 \%$ \\
\hline & Total & 193 & $100 \%$ \\
\hline
\end{tabular}

Based on the result of the analysis above, it is seen that the subject is dominated by the high categorization which is $59.1 \%$ or 114 people, then, on the very high categorization is around $36.3 \%$ or 70 people and on the normal one is $4.6 \%$ or 9 people.

The categorization of the career development perception scale could be seen on the following table:

Table 12 The categorization score of the career development perception

\begin{tabular}{llll}
\hline Range & Category & Amount & Percentage \\
\hline $\mathrm{X} \leq 43.95$ & Very low & 1 & $0.5 \%$ \\
& & 8 & $4.1 \%$ \\
$43.95<\mathrm{X} \leq 51.65$ & Low & & \\
& & 80 & $41.5 \%$ \\
$68.35<\mathrm{X} \leq 85.05$ & High & 98 & $50.8 \%$ \\
& & & \\
$85.05<\mathrm{X}$ & Normal & & \\
& Very high & 6 & $100 \%$ \\
\hline
\end{tabular}

Based on the result of the analysis above, it is seen that the subject is dominated on the high categorization that is $50.8 \%$ or 98 people, then the normal categorization which is $41.5 \%$ or 80 people, and the low categorization is about $4.1 \%$ or 8 people, and the very high categorization is $3.1 \%$ or 6 people, then the last one, the very low categorization is $0.5 \%$ or 1 person.

Before doing the hypothetical test, the researcher did the factor analysis first that was done on the three variables of the research: readiness for change, intrapreneurship, and career development perception. The factor analysis is a technique that is used to find some factors that can explain the relation or correlation of several independent indicators that are observed (Widarjono, 2010). The result 
of the factor analysis test reveals that the scale of the readiness for change, after the implementation of the factor analysis test, it is known that it has KMO MSA value around 0.813 and it is a multidimensional scale. At first, the readiness for change has four compiling aspects, yet after the implementation of the factor analysis, it changes into three factors that consist of self-efficacy, appropriateness, and management support in which each factor has some items. Self-efficacy factors have six items, the appropriateness factor consists of five items, and the management support factor has six items. The reliability of each factor such as self-efficacy is 0,689 , the appropriateness is 0.789 and the management support is 0.851. The scale of the intrapreneurship has KMO MSA value around 0.804 and it is a unidimensional scale that integrates into one factor called intrapreneurship, in which the result of the factor analysis shows that there is one aborted item so that there are 22 items available in the intrapreneurship. Afterward, the researcher did the reliability test again and the researcher got the reliability value around 0.846 .

After the implementation of the factor analysis test, the KMO MSA value of the scale of the career development perception is 0.880 and it is multidimensional. The perception of the career development at first has four compiling aspects, yet after the implementation of the factor analysis, it turns into 2 factors given two new names by the researcher namely the external system and the readiness of making a career in a company. It has one aborted item and the factor of the external system has 13 items, while the factor of the readiness for making a career in a company has 6 items. The reliability of each factor is the reliability value on the external system is 0.882 and the reliability of the readiness of making a career in a company around 0.680 .

Then, the researcher did the hypothesis test to fulfill the hypothesis that had been proposed by the researcher. The researcher utilizes the doubled regression analysis method with the help of IBM SPSS Statistic 22. Before doing the hypothesis test, the researcher changes the value of each score from every variable such as readiness for change, intrapreneurship, and the career development perception into $\mathrm{Z}$ score and then it changes again into $\mathrm{T}$ score, the change of the score is done by using a program called IBM SPSS Statistic 22, the aim of changing it into T score is to equal the value from the multidimensional variable.

The doubled regression analysis is used to see the relation between the independent variable and the dependent variable. The result of the hypothesis test is shown as follows:

Table 13 The result of the F test

\begin{tabular}{|c|c|c|c|c|c|}
\hline Model & Sum Square & Df & Mean Square & $\mathrm{F}$ & Sig. \\
\hline 1 Regression & 32954.450 & 1 & 32954.450 & 96.331 & $0.000^{\mathrm{b}}$ \\
\hline Residual & 65340.094 & 191 & 342.095 & & \\
\hline Total & 98294.544 & 192 & & & \\
\hline 2 Regression & 40712.932 & 2 & 20356.466 & 67.170 & $0.000^{c}$ \\
\hline Residual & 57581.612 & 190 & 303.061 & & \\
\hline Total & 98294.544 & 192 & & & \\
\hline
\end{tabular}

Based on the data above, the model 1 obtains $\mathrm{F}$ value around 96.331 with its sig value about 0.000 $(\mathrm{p}<0.05)$ and the predictor of the career development perception, it reflects that the career development perception is a predictor for readiness for change variable. If it is seen from the model 2 with $\mathrm{F}$ value 
around 67.170 and its sig value is $0.000(\mathrm{p}<0.05)$, thus it can be concluded that the hypothesis is accepted, it means that the intrapreneurship variable and the career development perception are the predictors toward the readiness for change variable at the same time.

This research also sees the effective contribution given from the intrapreneurship variable and the career development perception toward the variable of readiness for change, as it explains in table 14 as follows:

Table 14 The result of the correlation of the career development perception, intrapreneurship toward the readiness for change

\begin{tabular}{|c|c|c|c|c|}
\hline Model & $\mathrm{R}$ & R Square & Adjusted R Square & Std. Error of the Estimate \\
\hline 1 & 0.664 & 0.414 & 0.408 & 17.40865 \\
\hline
\end{tabular}

The result of $\mathrm{R}$ Square shows that the number 0.414 or $41.4 \%$. In this way, indeed, the amount of the effective contribution of the intrapreneurship variable and the career development perception is equal to $41.4 \%$, meanwhile, the rest of it (58.6\%) goes to other variables outside the research. The researcher also sees how many the effective contribution from each independent variable toward the dependent variable just likes in the following table:

Table 15 The effective contribution of the intrapreneurship variable and the career development perception

\begin{tabular}{|c|c|c|c|c|}
\hline \multirow{2}{*}{ Model } & \multicolumn{2}{|c|}{ Unstandardized Coefficients } & \multirow{2}{*}{$\begin{array}{l}\text { Standardized Coefficients } \\
\text { Beta }\end{array}$} & \multirow{2}{*}{$\begin{array}{l}\text { Correlation } \\
\text { Zero-Order }\end{array}$} \\
\hline & B & Std. Error & & \\
\hline (Constant) & -14.707 & 6.529 & & \\
\hline $\begin{array}{l}\text { The career } \\
\text { development } \\
\text { perception }\end{array}$ & 0.602 & 0.080 & 0.458 & 0.579 \\
\hline Intrapreneurship & 0.692 & 0.137 & 0.306 & 0.487 \\
\hline
\end{tabular}

From the result of the coefficient value, it also can be seen that the contribution provided by each variable by multiplying the Beta Value with the Zero Order. It shows that the career development perception gives an effective contribution toward the readiness for change under the value of around 0.265 or $26.5 \%$. The intrapreneurship variable provides an effective contribution toward the readiness for change variable around 0.149 or $14.9 \%$.

\section{Discussion}

Based on the result of the analysis that has been done by using the doubled regression analysis, the hypothesis of the research that is the intrapreneurship and the career development perception are the predictors of the readiness for change is acceptable. It can be seen from the result of the signification between two independent variables and one dependent variable with $\mathrm{F}$ value around 67.170 and the significance value around $0.000(\mathrm{p}<0.05)$. It shows that the intrapreneurship variable and the career development perception variable at the same time is the predictors of the readiness for change variable. If 
it is seen from the analysis of each variable, both the intrapreneurship variable and the career development perception of each have a significant value of around $0.000(\mathrm{p}<0.05)$. It shows that the intrapreneurship and the career development perception variables are the predictors toward the variable of the readiness for change.

The finding of this research is parallel with the research that had been conducted by Friana dan Indriana (2015) in which it explains intrapreneurship influences toward growth and improvement. In this case, it applies to the company facing a change and challenge that is getting more competitive, thus, it needs a sustainable growth and improvement. This improvement which always causes a change in the system of the organization and the duty is given. Utama (2013) also explained that through intrapreneurship, it will influence the improved performance of the employees. It is needed for each employee to build readiness in handling a change that can happen anytime, hence employee needs to have readiness in facing a change. It is in accordance with the career development perception, in which the employee that has a good career development perception in his or her company will be needed. In this case, he or she is needed to build a positive culture inside the company (Melinda \& Zulkarnain, 2004). This finding is related to the company that has a duty on keeping growth needs a change in his or her organization, thus it needs a readiness for change on each employee. The employee having a good career development perception will also keep working on his or her company (Liang \& Hsieh, 2005). It is needed by the company in which the employee who holds on their duty will act as an agent of change and influence to others.

Based on the result of the effective contribution analysis, the total of the intrapreneurship variable and the career development perception variable at the same time provides an effective contribution that is known from the value of $\mathrm{R}^{2}=0.414$. It explains that at the same time intrapreneurship and the career development perception are able to provide effective contribution around $41.4 \%$ and becomes the predictors of the readiness for change. There is still $58.6 \%$ readiness for change can be influenced by another factor such as leadership style, and type of personality (Narulita \& Meiyanto, 2014), culture organization (Haryanto, 2018), employee engagement (Nuraini, 2017) and organizational commitment (Pranatha \& Majorsy, 2018).

If it is seen from the effective contribution of each variable, it shows that the variable of the career development perception influences more on the readiness for change variable around $26.5 \%$. While the intrapreneurship one provides an effective contribution to the readiness for change variable around $14.9 \%$. It reflects that the readiness for change has two predictors namely the career development perception as the first predictor and the intrapreneurship as the second predictor. This finding is in accordance with the research done by Pradana (2010) which talked about the perception of the career development of the employee in a company. This research rises due to the global competition that is getting more competitive, that is why it needs competitiveness from its human resource. It relates to the readiness for change of the employee in which the company that always keep improving its human resource in order to cope with the challenge to make the company better. Hence, it needs a readiness for change from the employee of the aforementioned company. Tarigan \& Zulkarnain (2006) also explains that the employee with a good career development perception tends to stay and hold on his or her company. In this way, these employees become the agent of improvement in their company.

The intrapreneurship also explained that the atmosphere in Indonesia is uncertain and full of challenges and competition (Dhewanto, 2013). Therefore, it requires the Indonesia company to always be ready and reactive toward a change, this situation forces the company to leave out from the comfort zone and compete to survive. In this case, the answer is given through entrepreneurship, and the employee of the company needs to have an intrapreneurship. Intrapreneurship is also able to improve the performance inside a company (Felicio, Rodrigues, \& Caldeirinha, 2012). This improvement needs to be owned by the employee when he or she faces a change requiring him or her to develop from the organization. Intrapreneurship that is at first started as a concept to describe innovation in a big company, then it has been evolving into something to improve the performance of the company (Baruah \& Ward, 2015) thus it is needed to handle a change inside the organization.

The analysis of the demography data that is viewed by implementing the difference test toward the readiness for change showing that there is no significant difference in readiness for change based on the demography factor. This finding reveals that the readiness for change in Company X does not experience the difference whether it is seen from the factor of gender, age, duration of work, the degree of education, the degree of the employee's status or position in the company. This analysis reflects that the readiness for change is needed for all employees to make them capable of handling the not only challenge of their jobs now, e.g. a change in the company system but also in facing the global challenge that is getting more competitive. 
Viewing from the established categorization score, the employee of Company X is on high level related to the categorization of the readiness for change, it explains that the average of the employee has a high readiness for change, and he or she is ready to face not only the dynamic of duty but also the works system where he or she works. If it is seen from the categorization of its intrapreneurship score, the employee is included in the high categorization showing that intrapreneurship owned by the employee of Company $\mathrm{X}$ has innovation, proactive, and also can do risk-taking toward his or her duty in a company. The third categorization is the categorization score of the career development perception, the average of the employee is on high and normal category. Comparing the categorization of readiness for change and intrapreneurship, the normal category on the career development perception is also dominant. It also reveals that it takes more concern toward the career development of the employee at Company X.

\section{Conclusion}

Based on the result of the research and the analysis that has been done, a conclusion can be drawn as follows: the intrapreneurship variable and the career development perception variable are the predictors of the readiness for change variable, in which the career development perception is the first predictor, and the intrapreneurship is the second predictor. The intrapreneurship variable and the career development perception variables at the same time provide an effective contribution of around $41.4 \%$. The career development perception gives effective contribution around $26.5 \%$ followed by intrapreneurship variable providing effective contribution around $14.9 \%$. There is no difference viewed from gender, age, duration of work, education, and the degree of status based on the demography data toward the readiness for change variable. The categorization of the research data shows that the categorization score on the readiness for change variable and intrapreneurship is dominant in high categorization, while the career development perception is dominant in the normal and high categorization.

From the result of the research, the researcher offers suggestions for instance: the suggestion for the organization, the company needs to arrange a career development program that provides an opportunity for the employee to always be improved and progressed. Besides, the company has to give an opportunity to the employee to develop its intrapreneurship characteristics by giving a duty and work projects that train innovation, bravery to take a risk, and proactive in doing their job. Meanwhile, the suggestion for the employee is by making a self-improvement program toward the skills need improving. In addition, the employee needs to be more active in joining the intrapreneurship training program that can improve his or her skill in innovation, proactive, and risk-taking on his or herself. Then, the suggestion for the following researcher is that by spreading the data not only in one state-owned company (BUMN), thus the data could be more diverse and add the amount data of the sample, specifically on the higher position or the managing director of the company.

\section{References}

Alsa, A. (2007). Pendekatan Kuantitatif dan Kualitatif serta Kombinasi dalam Penelitian Psikologi. Yogyakarta: Pustaka Pelajar.

Amir, T. (2016). Coporate Entrepreneurship \& Innovation. Jakarta Timur: Kencana.

Baruah, B., \& Ward, A. (2015). Metamorphosis of Intrapreneurship as an Effective Organizational Strategy. International Entrepreneurship and Management Journal, 11(4), 811-822.

Batch, J., Castaneda, M. E., \& Farah, J. E. (2013). Employee Resistance to Organizational Change. IJM \& IS, $17(2), 113-116$.

BUMN. (2017). Daftar BUMN. Retrieved from http://www.bumn.go.id/halaman/situs

Choi, M., \& Ruona, W. E. (2011). Individual Readiness for Organizational Change and Its Implication for Human Resource and Organizational Development. HRD Review, 10, 46-73. 
Deinta, V. (2013). Hubungan Gaya Kepemimpinan Transformasional pada Atasan Langsung terhadap Perilaku Intrapreneur Karyawan di PT, X. Universitas Ciputra, Surabaya: Skripsi (not published). Fakultas Psikologi.

Dhewanto, W. (2013). Intrapreneurship Kewirausahaan Korporasi. Bandung: Penerbit Rekayasa Sains.

Felicio, J. A., Rodrigues, R., \& Caldeirinha, V. R. (2012). The Effect of Intrapreneurship on Corporate Performance. $M D, 50(10), 1717-1738$.

Flippo, E. B., \& Sirait, A. (1992). Manajemen Personalia I. Jakarta: Erlangga.

Friana, R., \& Indriana, I. (2015). Pengaruh Intrapreneurship terhadap Kinerja Perusahaan Manufaktur di Tangerang. JM, 19(1), 14-27.

Hanpachern, C., Morgan, G. A., \& Griego, O. V. (1998). An Extension of the Theory of Margin : A Framework for Assessing Readiness for Change. HRD Quarterly, 9(4), 339-350.

Haryanto, K. W. (2018). Pengaruh Budaya Organisasi terhadap Tingkat Kesiapan Organissi untuk Berubah. Universitas Sanata Dharma, Yogyakarta: Skripsi (not published). Fakultas Psikologi.

Holt, D. T., Armenakis, A. A., Feild, H. S., \& Harris, S. G. (2007). Readiness for Organizational Change The Systematic Development of a Scale. The JABS, 43(2), 232-255.

Jong, J. D., Parker, S., Wennekers, S., \& Wu, C. (2011). Corporate Entrepreneurship at the Individual Level : Measurement and Determinants. SAE and SMEs.

Karimi, A., Malekmohamadi, I., Daryani, M. A., \& Rezvanfar, A. (2011). A Conceptual Model of Intrapreneurship in the Iranian Agricultural Extension Organization Implication for HRD. JEIT, 35(7), 632-657.

Kasali, R. (2010). Myelin. Jakarta: Gramedia.

Kasali, R. (2014). Let’s Change. Jakarta: PT Kompas Media Nusantara.

Kreitner, R., \& Kinicki, A. (2005). Perilaku Organisasi (Edisi 5 Buku 2). Jakarta: Penerbit Salemba Empat.

KSG. (2017). Berubah Menyikapi Perubahan. In KSG NEWS, Berubah Menyikapi Perubahan (Wawancara Direktur Utama PT Krakatau Steel (Persero) Tbk. (pp. 1-3). Cilegon: Divisi Corporate Communication.

Kurnia, A., \& Simarmata, N. (2014). Intrapreneurship dan Pengambilan Keputusan pada Manajer Toko Modern. $J P U, 1(3), 451-461$.

Kurniawan, S. (2015). Revolusi Mental Making Indonesia WOW. Jakarta: Marketeers.

Liang, S. C., \& Hsieh, U. T. (2005). Individual's Perception of Career Development and Job Burn Out Among Flight Attendants in Taiwan. The IJAP, 15(2), 119-134.

Melinda, T., \& Zulkarnain. (2004). Budaya Perusahaan dan Persepsi Pengembangan Karir pada Karyawan yang Bekerja di PT. Telekomunikasi Indonesia. Jurnal Psikologi, 31(1), 55-62.

Narulita, E., \& Meiyanto, S. (2014). Kesiapan Karyawan dalam Menghadapi Perubahan ditinjau dari Gaya Kepemimpinan dan Tipe Kepribadian. Jurnal Pemikiran Dan Penelitian Psikologi, 19(1), $25-37$.

Nuraini, Y. (2017). Pengaruh Employee Engagement terhadap Kesiapan Karyawan untuk Berubah. Medan: Skripsi (not published). Fakultas Psikologi Universitas Sumatera Utara.

Periantalo, J. (2016). Penelitian Kuantitatif untuk Psikologi. Yogyakarta: Pustaka Pelajar.

Pradana, A. E. (2010). Persepsi terhadap Pengembangan Karir pada Staf Karyawan PT, Bina Busana Internusa. 
$J P, 8(2), 59-66$.

Pranatha, N. R. D., \& Majorsy, U. (2018). Komitmen Organisasi dan Kesiapan untuk Berubah pada Karyawan Media Cetak. JIP, 11(1), 25-34.

Santoso, S. (2014). Statistik Parametrik Konsep dan Aplikasi dengan SPSS. Jakarta: PT Elex Media Komputindo.

Sugiyono. (2015). Metode Penelitian Kombinasi (Mixed Methods). Bandung: Penerbit Alfabeta.

Tarigan, B. M., \& Zulkarnain. (2006). Persepsi Pengembangan Karier dan Intensi Turnover pada Karyawan yang Bekerja pada Public Service Coporate. PSIKOLOGIA, 2(2), 56-64.

Utama, I. G. (2013). Analisis Pengaruh Corporate Entrepreneurship terhadap Kinerja Industri Manufaktur di Jawa Timur. AGORA, 1(3), 1471-1475.

Widarjono, A. (2010). Analisis Statistika Multivariat Terapan. Yogyakarta: UPP STIM YKPN.

Yudiaatmaja, F. (2013). Analisis Regresi (Dengan Menggunakan Aplikasi Komputer Statistik SPSS). Jakarta: PT Gramedia.

Zulkarnain, S., \& Hadiyani. (2014). Peranan Komitmen Organisasi dan Employee Engagement terhadap Kesiapan Karyawan untuk Berubah. JP, 41(1), 17-33. 